\title{
PENGARUH KESELAMATAN KERJA DAN KESEHATAN KERJA TERHADAP KINERJA DENGAN KEPUASAN KERJA SEBAGAI VARIABEL INTERVENING \\ (Studi Kasus pada Karyawan Bagian Produksi Unit Serbuk Effervescent PT Sido Muncul Semarang)
}

\author{
Oleh : \\ Endro Wibowo \\ Alumni STIE AMA Salatiga \\ Hardi Utomo \\ Dosen Tetap STIE AMA Salatiga
}

\begin{abstract}
Abstrak
Tujuan penelitian ini adalah untuk menguji pengaruh keselamatan dan kesehatan kerja (K3) terhadap kinerja dengan kepuasan kerja sebagai variabel intervening pada Karyawan Bagian Produksi Unit Serbuk Effervescent PT Sido Muncul Semarang. Sampel dalam penelitian ini adalah karyawan produksi bagian unit serbuk effervescent yaitu sebanyak 65 responden.. Pemilihan sampel dalam penelitian ini menggunakan nonprobability sampling dimana sebagian populasi dijadikan sampel.Alat analisis yang digunakan adalah analisis path (analisis jalur).

Hasil analisis menunjukkan bahwa variabel keselamatan kerja berpengaruh signifikan terhadap kinerja dengan thitung $>t_{\text {tabel }}$ dengan hasil thitung $>t_{\text {tabel }}: 2,953>2,000$, variabel kesehatan kerja berpengaruh signifikan terhadap kinerja dengan thitung $>t_{\text {tabel }}: 2,736>2,000$, variabel keselamatan kerja berpengaruh signifikan terhadap kepuasan pelanggan dengan thitung > $t_{\text {tabel }}: 2,350>2,000$, variabel kesehatan kerja berpengaruh signifikan terhadap kepuasan pelanggan dengan thitung $>t_{\text {tabel }}: 2,757>2,000$, variabel kepuasan kerja berpengaruh signifikan terhadap kinerja dengan thitung $>t_{\text {tabel }}: 2,085>$ 2,000 dan keselamatan kerja dan kesehatan kerja secara tidak langsung berpengaruh signifikan terhadap kinerja karyawan melalui kepuasan kerja sebagai variabel intervening dengan nilai pengaruh tidak langsung keselamatan kerja terhadap kinerja > nilai pengaruh langsung keselamatan kerja terhadap kinerja : 0,444>0,357 dan nilai pengaruh tidak langsung kesehatan kerja terhadap kinerja > nilai pengaruh langsung kesehatan kerja terhadap kinerja : 0,483 > 0,318. Dari perhitungan koefisien determinasi diperoleh kadar koefisien determinasi variael laten lokasi, harga dan promosi sebesar 0,512. Hal ini menunjukkan sekitar 51,2\% faktor kinerja dapat dijelaskan oleh faktor keselamatan kerja, kesehatan kerja dan kepuasan kerja sedangkan 48,8\% dipengaruhi oleh faktor lain seperti budaya organisasi, pendapatan dan iklim kerja.
\end{abstract}

Kata kunci: keselamatan kerja, kesehatan kerja, kinerja dan kepuasan kerja 


\section{PENDAHULUAN}

Sumber daya manusia merupakan peranan penting bagi keberhasilan suatu organisasi atau perusahaan, karena manusia merupakan aset hidup yang perlu dipelihara dan dikembangkan.Oleh karena itu karyawan harus mendapatkan perhatian yang khusus dari perusahaan.

Seperti yang telah dikutip Detik Finance (Oktober 2012) Keselamatan dan perlindungan tenaga kerja di Indonesia ternyata masih minim. Ini terlihat dari banyaknya jumlah kecelakaan kerja tahun 2011 dengan jumlah 96.400 kecelakaan.Dari 96.400 kecelakaan kerja yang terjadi, sebanyak 2.144 diantaranya tercatat meninggal dunia dan 42 lainnya cacat.Sampai September 2012 angka kecelakaan kerja masih tinggi yaitu pada kisaran 80.000 kasus kecelakaan kerja. Data Internasional Labor Organization (ILO) menghasilkan kesimpulan bahwa dalam rentan waktu rata-rata per tahun terdapat 99.000 kasus kecelakaan kerja dan $70 \%$ di antaranya berakibat fatal yaitu kematian dan cacat seumur hidup.

Keselamatan kerja dan kesehatan kerja adalah upaya untuk menjamin dan menjaga kesehatan serta keutuhan jasmani dan rohani para tenaga kerja khusunya manusia, untuk menuju masyarakat yang adil dan makmur (Mangkunegara, 2009:123).Keselamatan kerja dan kesehatan kerja termasuk salah satu program pemeliharaan yang ada di perusahaan.Pelaksanaan program keselamatan kerja dan kesehatan kerja bagi karyawan sangatlah penting karena bertujuan untuk menciptakan sistem keselamatan dan kesatuan kerja dengan melibatkan unsur manajemen, tenaga kerja, kondisi dan lingkungan kerja yang terintegrasi dalam rangka mengurangi kecelakaan. Masalah keselamatan kerja kesehatan dan kerja bukan hanya semata-mata tanggung jawab pemerintah saja melainkan tanggung jawab semua pihak yaitu pengusaha, tenaga kerja dan masyarakat.

Keselamatan kerja dan kesehatan kerja merupakan hal yang paling penting bagi perusahaan, karena dampak kecelakaan dan penyakit kerja tidak hanya merugikan karyawan, tetapi juga merugikan perusahaan.Keselamatan kerja menurut Mondy (2008:360) adalah perlindungan karyawan dari cidera yang disebabkan oleh kecelakaan yang berkaitan dengan pekerjaan.Dan Kesehatan kerja menurut Mathias dan Jakson (2007:245) adalah kondisi yang merujuk pada kondisi fisik, mental dan 
stabilitas emosi secara umum.

Menurut Mathis dan Jackson (2007:113), kinerja mengacu pada prestasi karyawan yang diukur berdasarkan standar atau kriteria yang ditetapkan perusahan. Kepuasan kerja sangat diperlukan dan diharapkan akan dapat bekerja pada kapasitas penuh, sehingga akan meningkatkan kinerja organisasi. Sebaliknya jikapegawai tidak merasa puas dalan kinerjanya maka akan terjadi kondisi penuruan kinerja mereka.

PT.Sido Muncul Tbk. merupakan salah satu perusahaan yang bergerak pada bidang produksi jamu dan farmasi,dalam pelaksanannya membutuhkan sistem manajemen keselamatan kerja dan kesehatan kerja yang baik sehingga mampu mencetak karyawan berkualitas dan mampu mendukung pencapaian tujuan perusahaan secara optimal. Mengingat luasnya kegiataan produksi jamu dan farmasi yang dilakukan oleh perusahaan, maka ruang lingkup penelitian ini dibatasi dalam sistem manajemen keselamatan kerja dan kesehatan kerja pada unit serbuk effervescent.

Dalam pelaksanaannya unsur keselamatan dan kesehatan kerja di PT Sido Muncul telah menjadi salah satu prosedur standar operasional dalam Cara Membuat Obat Tradisional yang Baik (CPOTB) dan Cara Pembuatan Obat yang Baik (CPOB), namun PT Sido Muncul belum memiliki sertifikat akreditasi Sistem Manajemen Keselamatan dan Kesehatan Kerja (SMK3) sehingga Perseroan atas persetujuan Dinas Sosial, Tenaga kerja dan Transmigrasi Kabupaten Semarang telah menunjuk Perusahaan Jasa Keselamatan dan Kesehatan Kerja (PJK3) dalam membantu proses akreditasi. Dalam penerapannya jumlah tenaga ahli K3 bersertifikat yang dimiliki masih kurang (44 personel) jika dibandingkan dengan jumlah karyawannya, tenaga ahli yang dibutuhkan oleh perseroan meliputi: Ahli K3 (AK3) Bangunan, Kimia dan Ahli Listrik

\section{RUMUSAN MASALAH}

Berdasarkan latar belakang dalam permasalahan tersebut diatas maka dapat disusun rumusan masalah penelitian adalah "Apakah ada pengaruh keselamatan kerja dan kesehatan kerja terhadap kinerja karyawan dengan kepuasan kerja sebagai 
variabel intervening bagian produksi Unit Serbuk Effervescent PT Sido Muncul Semarang?"

\section{TUJUAN PENELITIAN}

Tujuan Penelitian ini untuk mengetahui pengaruh keselamatan kerja dan kesehatan kerja terhadap kinerja karyawan dengan kepuasan kerja sebagai variabel intervening bagian produksi Unit Serbuk Effervescent PT Sido Muncul Semarang;

\section{LANDASAN TEORI}

\section{Keselamatan Kerja}

Keselamatan kerja menurut Mondy (2008:82) adalah perlindungan karyawan dari cidera yang disebabkan oleh kecelakaan yang berkaitan dengan pekerjaan.

Menurut Suma'mur, (2006:6), keselamatan kerja merupakan spesialisasi ilmu kesehatan beserta prakteknya yang bertujuan agar para pekerja atau masyarakat pekerja memperoleh derajat kesehatan setinggi-tingginya baik fisik, mental maupun sosial dengan usaha preventif dan kuratif terhadap penyakit/gangguan kesehatan yang diakibatkan oleh faktor pekerjaan dan lingkungan serta terhadap penyakit umum.

Keselamatan kerja merupakan keselamatan yang bertalian dengan mesin, pesawat, alat kerja, bahan dan pengolahannya, landasan tempat kerja dan lingkungannya serta cara-cara melakukan pekerjaan (Suma'mur, 2006:13).

\section{Kesehatan Kerja}

Konsep kesehatan kerja dewasa ini semakin banyak berubah, bukan sekedar "kesehatan pada sektor industri" saja melainkan juga mengarah pada upaya kesehatan untuk semua orang dalam melakukan pekerjaannya (Total healthof all at work).Dan ilmu ini tidak hanya hubungan antara efek lingkungan kerjadengan kesehatan, tetapi juga hubungan antara status kesehatan pekerja dengankemampuannya untuk melakukan tugas yang harus dikerjakannya, dan tujuan dari kesehatan kerja adalah mencegah timbulnya gangguan kesehatan daripada mengobatinya (Harrington, 2005:81).

Menurut Mathias dan Jakson (2007:245) adalah kondisi yang merujuk pada kondisi fisik, mental dan stabilitas emosi secara umum.Individu yang sehat 
adalah individu yang bebas dari penyakit, cidera serta masalah mental emosi yang bisa menggangu aktivitas.Kesehatan kerja adalah upaya untuk menjamin dan menjaga kesehatan serta keutuhan jasmani dan rohani para tenaga kerja khususnya manusia, menuju masyarakat yang adil dan makmur (Mangkunegara, 2009:123).

\section{Keselamatan dan Kesehatan Kerja (K3)}

Keselamatan dan Kesehatan Kerja (K3) secara harfiah terdiri dari tiga suku kata, yaitu keselamatan, kesehatan, dan kerja.Keselamatan dalam bahasa Inggris disebut safety yang berarti keadaan terbebas dari celaka dan hampir celaka (Geotsch dalam Rizky, 2009:10).Sedangkan kesehatan adalah dalam bahasa Inggris disebut health, kesehatan menurut UU RI No. 36 tahun 2009 ialah"Keadaan sehat, baik secara fisik, mental, spritual maupun sosial yang memungkinkan setiap orang untuk hidup produktif secara sosial dan ekonomis.'Definisi terakhir ialah definisi mengenai kerja.Kerja dalam bahasa Inggris disebut work atau occupation yang berarti kegiatan atau usaha untuk mencapai tujuan(pengahasilan dan lain-lain) (Geotsch dalam Rizky, 2009:12).

Keselamatan kerja merupakan keselamatan yang bertalian dengan mesin, pesawat, alat kerja, bahan dan pengolahannya, landasan tempat kerja dan lingkungannya serta cara-cara melakukan pekerjaan (Suma'mur, 2006:17). Undang-Undang No. 1 Tahun 1970 dalam menerangkan bahwa keselamatan kerja yang mempunyai ruang lingkup yang berhubungan dengan mesin, landasan tempat kerja dan lingkungan kerja, serta cara mencegah terjadinya kecelakaan dan penyakit akibat kerja, memberikan perlindungan sumber-sumber produksi sehingga dapat meningkatkan efisiensi dan produktifitas.

Menurut Suma'mur, (2006:13), keselamatan kerja merupakan spesialisasi ilmu kesehatan beserta prakteknya yang bertujuan agar para pekerja atau masyarakat pekerja memperoleh derajat kesehatan setinggi-tingginya baik fisik, mental maupun sosial dengan usaha preventif dan kuratif terhadap penyakit/gangguan kesehatan yang diakibatkan oleh faktor pekerjaan dan lingkungan serta terhadap penyakit umum.

\section{Kinerja Karyawan}

Istilah kinerja merupakan terjemahan dari performance yang sering diartikan 
oleh para cendekiawan sebagai penampilan, unjuk kerja atau prestasi (Keban, 2008:191).

Berbeda dengan Bernardin dan Russel dalam Keban (2008:192) mengartikan kinerja sebagai "the record of outcomes produced on a specified jobfunction or activity during a specified time period". Dalam definisi ini, aspekyang ditekankan oleh kedua pengarang tersebut adalah catatan tentang outcome atau hasil akhir yang diperoleh setelah suatu pekerjaan atau aktivitas dijalankan selama kurun waktu tertentu. Dengan demikian kinerja hanya mengacu pada serangkaian hasil yang diperoleh seorang pegawai selama periode tertentu dan tidak termasuk karakteristik pribadi pegawai yang dinilai, sedangkan Suyadi Prawirosentono (2008:2) mendefinisikan kinerja sebagai performance, yaitu hasil kerja yang dapat dicapai oleh seseorang atau sekelompok orang dalam suatu organisasi, sesuai dengan wewenang dan tanggung jawab masing-masing, dalam rangka upaya mencapai tujuan organisasi bersangkutan secara legal, tidak melanggar hukum dan sesuai dengan moral dan etika.

\section{Kepuasan Kerja}

Menurut Kreitner dan Kinicki (2005:271) kepuasan kerja adalah "suatu efektifitas atau respons emosional terhadap berbagai aspek pekerjaan”. Davis danNewstrom (2008:105) mendeskripsikan "kepuasan kerja adalah seperangkat perasaan pegawai tentang menyenangkan atau tidaknya pekerjaan mereka".Menurut Robbins (2006:78) kepuasan kerja adalah "sikap umum terhadap pekerjaan seseorang yang menunjukkan perbedaan antara jumlah penghargaan yang diterima pekerja dan jumlah yang mereka yakini seharusnya mereka terima”.

Menurut Hasibuan (2007:202) kepuasan kerja adalah sikap emosional yang menyenangkan dan mencintai pekerjaan.Sikap ini dicerminkan oleh moral kerja, kedisiplinan dan prestasi kerja.Kepuasan kerja dinikmati dalam pekerjaan, luar pekerjaan dan kombinasi dalam dan luar pekerjaan.Menurut Handoko (2008:193) kepuasan kerja adalah keadaan emosional yang menyenangkan atau tidak menyenangkan dimana para karyawan memandang pekerjaan.Kepuasan kerja mencerminkan perasaan seseorang terhadap pekerjaannya. 


\section{Kerangka Pemikiran}

Kerangka pemikiran merupakan abstraksi dari fenomena - fenomena yang sedang diteliti. Dalam hal ini kerangka penelitian mengeni pengaruh keselamatan dan kesehatan kerja (K3) terhadap kinerja dengan kepuasan kerja sebagai variabel

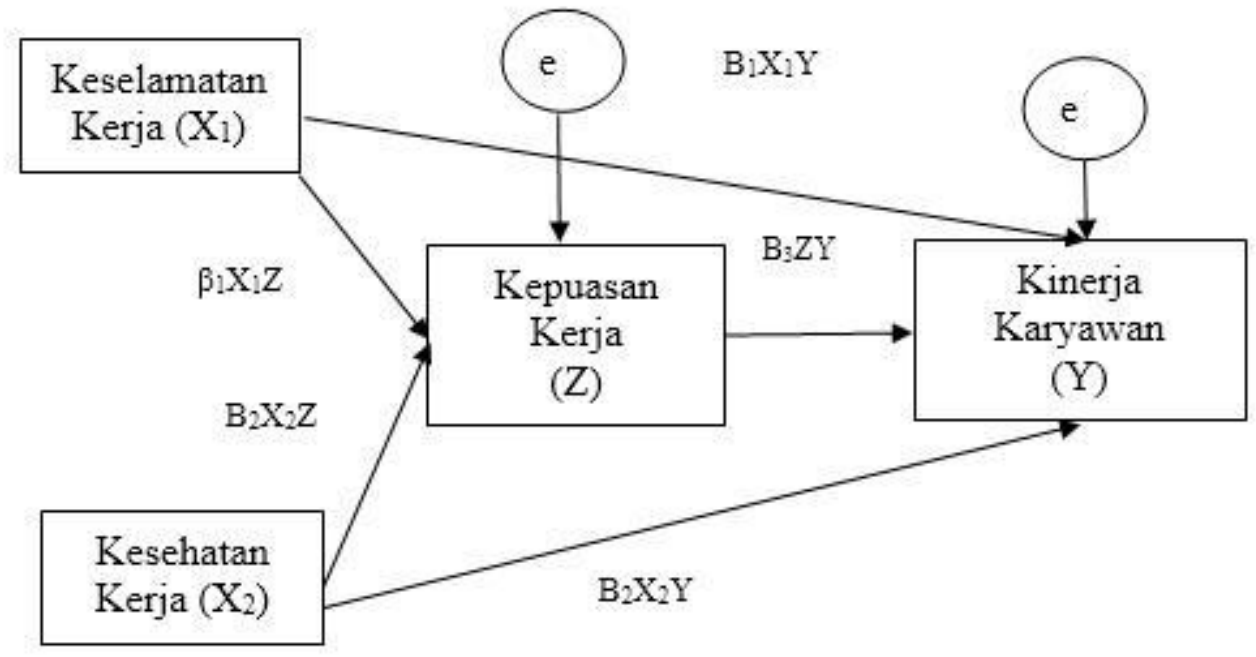

intervening.

Gambar 1

\section{Hipotesis}

\section{Kerangka Pemikiran Penelitian}

Hipotesis merupakan jawaban sementara terhadap rumusan masalah penelitian dimana masalah penelitian telah dinyatakan dalam bentuk kalimat pertanyaan (Sugiyono, 2010: 64). Berdasarkan kerangka pemikiran teoritis di atas, maka hipotesis yang diajukan dalam penelitian ini yaitu:

H1: Terdapat pengaruh signifikan keselamatan kerja terhadap kinerja karyawan.

H2: Terdapat pengaruh signifikan kesehatan kerja terhadap kinerja karyawan.

H3: Terdapat pengaruh signifikan keselamatan kerja terhadap kepuasan kerja karyawan.

H4: Terdapat pengaruh signifikan kesehatan kerja terhadap kepuasan kerja karyawan.

H5: Terdapat pengaruh signifikan kepuasan kerja terhadap kinerja karyawan.

H6: Terdapat pengaruh signifikan keselamatan kerja terhadap kinerja dengan kepuasan kerja sebagai variabel intervening.

H7: Terdapat pengaruh signifikan kesehatan kerja terhadap kinerja dengan 
kepuasan kerja sebagai variabel intervening.

\section{METODE PENELITIAN}

\section{Jenis Penelitian}

Jenis penelitian yang digunakan berdasarkan tujuan penelitian adalah penelitian eksplanatori, yaitu untuk mengetahui pengaruh antar variabel baik parsial maupun simultan karena bertujuan untuk menjelaskan pengaruh antara dua atau lebih gejala atau variabel yaitu pengaruh variabel bebas (keselamatan kerja dan kesehatan kerja) terhadap variabel terikat (kinerja) melalui variabel intervening (kepuasan kerja).

\section{Populasi dan Sampel}

Menurut Arikunto (2010:130) populasi adalah keseluruhan subyek penelitian. Populasi dalam penelitian ini adalah seluruh karyawan produksi bagian serbuk evervecent dari data Human Resources Development PT Sido Muncul tahun 2014 yang berjumlah 189 orang. Jumlah Sampel dalam penelitian ini adalah sebanyak 65 karyawan, teknik pengambilan sampel yang digunakan dalam penelitian ini adalah nonprobability sampling

\section{Definisi Konsep dan Definisi Operasional}

Tabel 1

Definisi Operasional Variabel

\begin{tabular}{|c|c|c|c|c|}
\hline No. & Variabel & Definisi & Indikator & Skala \\
\hline 1. & $\begin{array}{c}\text { Keselamatan } \\
\text { Kerja }\end{array}$ & $\begin{array}{l}\text { Praktik yang bertujuan } \\
\text { agar para pekerja atau } \\
\text { masyarakat pekerja } \\
\text { memperoleh derajat } \\
\text { kesehatan setinggi- } \\
\text { tingginya baik fisik, } \\
\text { mental maupun sosial } \\
\text { dengan usaha preventif } \\
\text { dan kuratif terhadap } \\
\text { penyakit/gangguan } \\
\text { kesehatan yang } \\
\text { diakibatkan oleh faktor } \\
\text { pekerjaan dan lingkungan } \\
\text { serta terhadap penyakit } \\
\text { umum. (Suma'mur, } \\
\text { 2006:6) }\end{array}$ & $\begin{array}{l}\text { 1. Lingkungan } \\
\text { tempat kerja } \\
\text { 2. Mesin dan } \\
\text { peralatan } \\
\text { 3. Jaminan } \\
\text { Keselamatan } \\
\text { (Suma'mur, } \\
\text { 2006:17) }\end{array}$ & Ordinal \\
\hline
\end{tabular}




\begin{tabular}{|c|c|c|c|c|}
\hline 2. & $\begin{array}{c}\text { Kesehatan } \\
\text { Kerja }\end{array}$ & $\begin{array}{l}\text { Upaya untuk menjamin } \\
\text { dan menjaga kesehatan } \\
\text { serta keutuhan jasmani } \\
\text { dan rohani para tenaga } \\
\text { kerja khususnya manusia, } \\
\text { menuju masyarakat yang } \\
\text { adil dan makmur } \\
\text { (Mangkunegara, } \\
\text { 2009:123) }\end{array}$ & $\begin{array}{l}\text { 1. Kondisi alat } \\
\text { indera } \\
\text { 2. Stamina } \\
\text { 3. Emosi } \\
\text { 4. Program jaminan } \\
\text { kesehatan } \\
\text { (Mangkunegara, } \\
\text { 2009:124) }\end{array}$ & Ordinal \\
\hline 3. & $\begin{array}{c}\text { Kepuasan } \\
\text { Kerja }\end{array}$ & $\begin{array}{l}\text { Keadaan emosional yang } \\
\text { menyenangkan atau tidak } \\
\text { menyenangkan dimana } \\
\text { para karyawan } \\
\text { memandang pekerjaan } \\
\text { para karyawan } \\
\text { memandang pekerjaan } \\
\text { (Hasibuan, 2007:195). }\end{array}$ & $\begin{array}{l}\text { 1.Gaji } \\
\text { 2.Tata letak ruang } \\
\text { 3.Rekan kerja } \\
\text { 4.Dukungan Kerja } \\
\text { 5.Sapaan atasan } \\
\text { (Hasibuan, } \\
\text { 2007:375) }\end{array}$ & Ordinal \\
\hline 4 & Kinerja & $\begin{array}{l}\text { Hasil yang dicapai oleh } \\
\text { pekerja dalam } \\
\text { pekerjaannya menurut } \\
\text { kriteria tertentu yang } \\
\text { berlaku untuk suatu } \\
\text { pekerjaan Robbins } \\
(2006: 187) .\end{array}$ & $\begin{array}{l}\text { 1.Kuantitas } \\
\text { 2.Ketepatan waktu } \\
\text { 3.Efektivitas } \\
\text { 4.Kemandirian } \\
\text { 5.Komitmen kerja } \\
\text { (Robbins, } \\
\text { 2006:260) }\end{array}$ & Ordinal \\
\hline
\end{tabular}

\section{Metode Analisis Data}

\section{Uji Validitas}

Uji validitas yang dilakukan bertujuan untuk menguji sejauh mana item kuesioner yang valid dan yang tidak valid. Menurut Sugiyono (2010:116), syarat minimum suatu item dianggap valid adalah nilai $\mathrm{r}$ 0,30. Dimana semakin tinggi validitas suatu alat test, maka alat tersebut makin mengenai ke sasarannya, atau menunjukkan apa yang seharusnya diukur. Suatu test dapat dikatakan mempunyai validitas tinggi apabila hasil test tersebut menjalankan fungsi pengukurannya, atau memberikan hasil ukur sesuai dengan makna dan tujuan diadakannya test atau penelitian tersebut. Selanjutnya menentukan kevalidan dari item kuesioner digunakan metode koefisien korelasi Pearson Product Moment yaitu dengan mengkorelasikan skor total yang dihasilkan oleh masing-masing responden (Y) dengan skor masing-masing item (X) (Sugiyono, 2010:182).

\section{Uji Reliabilitas}

Reliabilitas adalah sejauh mana hasil suatu pengukuran dapat dipercaya, 
maksudnya apabila dalam beberapa pelaksanaan pengukuran terhadap kelompok yang sama diperoleh hasil yang relatif sama (Azwar, 2005:3). Dalam penelitian ini, uji reliabilitas dilakukan dengan menggunakan tekhnik Formula Alpha Cronbach.

Indikator pengukuran reliabilitas menurut Sekaran (2005:312) yangmembagi tingkatan reliabilitas dengan kriteria sebagai berikut : Jika alpha atau $r$ hitung: 1) 0,8-1,0 = Reliabilitas baik; 2)0,6-0,799 = Reliabilitas diterima;3)kurang dari 0,6 = Reliabilitas kurang baik

\section{Analysis Jalur (Path Analysis)}

Untuk melakukan analisis data, pengolahan data dilakukan menggunakan analisis jalur (path analysis).Kepuasan kerja diposisikan sebagai variabel intervening yang menghubungkan antara variabel dependen dan variabel independen. Metode path analysis merupakan perluasan regresi linier berganda yang digunakan untuk menaksir hubungan kausalitas antara variabel dalam model penelitian yang dibangun berdasarkan landasan teori yang kuat.

\section{Uji t}

Uji-t dipergunakan untu menguji pengaruh signifikan variabel independen terhadap variabel dependen dalam persamaan secara parsial.Bila signifikan berarti secara statistik hal ini menunjukkan bahwa variabel independen mempunyai pengaruh secara parsial terhadap variabel dependen.

Jika thitung $<-t_{\text {tabel }}$ atau jika thitung $>t_{\text {tabel }}$ maka Ha diterima. Jika thitung $>$ $\mathrm{t}_{\text {tabel }}$ dan thitung $<\mathrm{t}_{\text {tabel }}$ maka Ha ditolak.

\section{Koefisien Determinasi}

Koefisien determinasi ini berfungsi untuk mengetahui persentase besarnya pengaruh variabel independen dan variabel dependen.Dalam penggunaanya, koefisien determinasi ini dinyatakan dalam persentase $(\%)$. 


\section{PENYAJIAN DAN ANALISIS DATA}

\section{Deskripsi Data Responden Berdasarkan Usia}

Tabel 2

Pengelompokan Responden Berdasarkan Usia

\begin{tabular}{|c|c|c|c|}
\hline No. & Jenis Kelamin & Jumlah Responden & Presentase \% \\
\hline 1. & Dibawah 24 tahun & 3 & 4,615 \\
\hline 2. & $24-26$ tahun & 23 & 35,385 \\
\hline 3. & $27-29$ tahun & 28 & 43,077 \\
\hline 4. & $30-32$ tahun & 9 & 13,846 \\
\hline 5. & Diatas 32 tahun & 2 & 3,077 \\
\hline \multicolumn{2}{|c|}{ Jumlah } & $\mathbf{6 5}$ & $\mathbf{1 0 0}$ \\
\hline
\end{tabular}

Dari tabel 2 di atas, terlihat bahwa 3 responden $(4,615 \%)$ berusia dibawah 24 tahun, sebanyak 23 responden $(35,385 \%)$ berusia antara 24-26 tahun, sebanyak 27 responden $(43,077 \%)$ berusia antara 27-29 tahun, sebanyak 9 responden $(13,846 \%)$ berusia antara 30-32 tahun dan sebanyak 2 responden $(3,077 \%)$ berusia diatas 32 tahun.

\section{Data Responden Berdasarkan Lama Bekerja}

Tabel 3

Pengelompokan Responden Berdasarkan Lama Bekerja

\begin{tabular}{|c|c|c|c|}
\hline No. & Lama Bekerja & Jumlah Responden & Presentase\% \\
\hline 1. & Kurang dari 4 tahun & 4 & 6,154 \\
\hline 2. & 4 tahun & 11 & 16,923 \\
\hline 3. & 5 tahun & 17 & 26,154 \\
\hline 4. & 6 tahun & 18 & 27,692 \\
\hline 5. & 7 tahun & 13 & 20 \\
\hline 6. & Lebih dari 7 tahun & 1 & 1,534 \\
\hline \multicolumn{2}{|c|}{ Jumlah } & $\mathbf{6 5}$ & $\mathbf{1 0 0}$ \\
\hline
\end{tabular}

Dari tabel 3 di atas, terlihat bahwa 4 responden $(6,154 \% \%)$ bekerja kurang dari 4 tahun, 11 responden $(16,923 \%)$ telah bekerja selama 4 tahun, 17 responden $(26,154 \%)$ telah bekerja selama 5 tahun, 18 responden $(27,692 \%)$ telah bekerja selama 6 tahun, 13 responden (20\%) telah bekerja selama 7 tahun dan 1 responden $(1,534 \%)$ telah bekerja lebih dari 7 tahun.

\section{Analisis Data}

\section{Uji Validitas}

Uji coba instrumen telah dilakukan terhadap 65 responden menemukan 
bahwa semua indikator yang terdapat dalam angket keselamatan kerja, kesehatan kerja, kinerja dan kepuasan kerja dapat dinyatakan valid karena semua indikator mempunyai nilai lebih besar dari $r_{\text {tabel }}(0,325)$.

Tabel 4

Hasil Uji Validitas Variabel Keselamatan Kerja

\begin{tabular}{|l|c|c|c|}
\hline No. Item & $\boldsymbol{R} \boldsymbol{x y}$ & $\boldsymbol{r}_{\text {tabel }}$ & Keterangan \\
\hline ITEM01 & 0,727 & 0,325 & Valid \\
\hline ITEM02 & 0,765 & 0,325 & Valid \\
\hline ITEM03 & 0,709 & 0,325 & Valid \\
\hline ITEM04 & 0,582 & 0,325 & Valid \\
\hline ITEM05 & 0,347 & 0,325 & Valid \\
\hline
\end{tabular}

Uji validitas yang telah dilakukan terhadap variabel keselamatan kerja, seperti tampak pada tabel 5, menemukan bahwa 5 item pernyataan yang ada seluruhnya valid karena lebih besar dari 0,325.

Tabel 5

Hasil Uji Validitas Variabel Kesehatan Kerja

\begin{tabular}{|l|c|c|c|}
\hline No. Item & $\boldsymbol{R} \boldsymbol{x y}$ & $\boldsymbol{r}_{\text {tabel }}$ & Keterangan \\
\hline ITEM06 & 0,609 & 0,325 & Valid \\
\hline ITEM07 & 0,682 & 0,325 & Valid \\
\hline ITEM08 & 0,808 & 0,325 & Valid \\
\hline ITEM09 & 0,684 & 0,325 & Valid \\
\hline ITEM10 & 0,886 & 0,325 & Valid \\
\hline
\end{tabular}

Uji validitas yang telah dilakukan terhadap variabel keselamatan kerja seperti tampak pada tabel 6 , menemukan bahwa 5 item pernyataan yang ada seluruhnya valid karena lebih besar dari 0,325.

Tabel 6

Hasil Uji Validitas Variabel Kinerja

\begin{tabular}{|l|c|c|c|}
\hline No. Item & $\boldsymbol{R} \boldsymbol{x y}$ & $\boldsymbol{r}_{\text {tabel }}$ & Keterangan \\
\hline ITEM11 & 0,584 & 0,325 & Valid \\
\hline ITEM12 & 0,584 & 0,325 & Valid \\
\hline ITEM13 & 0,641 & 0,325 & Valid \\
\hline ITEM14 & 0,864 & 0,325 & Valid \\
\hline ITEM15 & 0,361 & 0,325 & Valid \\
\hline
\end{tabular}

Uji validitas yang telah dilakukan terhadap variabel kinerja seperti tampak pada tabel 7, menemukan bahwa 5 item pernyataan yang ada seluruhnya valid karena lebih besar dari 0,325. 
Tabel 7

Hasil Uji Validitas Variabel Kepuasan Kerja

\begin{tabular}{|l|c|c|c|}
\hline No. Item & $\boldsymbol{R} \boldsymbol{x y}$ & $\boldsymbol{r}_{\text {tabel }}$ & Keterangan \\
\hline ITEM16 & 0,739 & 0,325 & Valid \\
\hline ITEM17 & 0,648 & 0,325 & Valid \\
\hline ITEM18 & 0,800 & 0,325 & Valid \\
\hline ITEM19 & 0,730 & 0,325 & Valid \\
\hline ITEM20 & 0,420 & 0,325 & Valid \\
\hline
\end{tabular}

Uji validitas yang telah dilakukan terhadap variabel kepuasan kerja seperti tampak pada tabel 8 , menemukan bahwa 5 item pernyataan yang ada seluruhnya valid karena lebih besar dari 0,325.

\section{Uji Reliabilitas}

Tabel 8

Hasil Uji Reliabilitas

\begin{tabular}{|l|c|c|c|}
\hline \multicolumn{1}{|c|}{ Variabel } & Nilai Alpha & Pembanding & Keterangan \\
\hline Keselamatan Kerja & 0,643 & 0,60 & Reliabel \\
\hline Kesehatan Kerja & 0,636 & 0,60 & Reliabel \\
\hline Kinerja & 0,617 & 0,60 & Reliabel \\
\hline Kepuasan Kerja & 0,697 & 0,60 & Reliabel \\
\hline
\end{tabular}

Tabel 9 menunjukkan bahwa keempat variabel memiliki nilai alpha lebih besar dari 0,60. Hal ini bermakna bahwa angket keselamatan kerja, kesehatan kerja, kinerja dan kepuasan kerja dapat dinyatakan reliabel dan dapat digunakan sebagai alat ukur dalam penelitian.

\section{Analisis Jalur (Path Analysis)}

\section{Analisis Jalur Pengaruh Keselamatan Kerja (X1) dan Kesehatan Kerja (X2) terhadap Kepuasan Kerja (Z)}

Tabel 9

Hasil Uji Analisis Jalur Pengaruh Keselamatan Kerja (X1) dan Kesehatan Kerja (X2) terhadap Kepuasan Kerja (Z)

Coefficients $^{\mathrm{a}}$

\begin{tabular}{|ll|c|c|c|c|c|}
\hline \multirow{2}{*}{ Model } & \multicolumn{2}{|c|}{$\begin{array}{c}\text { Unstandardized } \\
\text { Coefficients }\end{array}$} & $\begin{array}{c}\text { Standardized } \\
\text { Coefficients }\end{array}$ & \multirow{2}{*}{$\mathrm{T}$} & \multirow{2}{*}{ Sig. } \\
\cline { 3 - 5 } & & $\mathrm{B}$ & Std. Error & Beta & & \\
\hline 1 & (Constant) & 6,221 & 3,164 & & 1,966 &, 054 \\
& Keselamatan_Kerja &, 399 &, 170 &, 542 & 2,350 &, 022 \\
& Kesehatan_Kerja &, 228 &, 083 &, 589 & 2,757 &, 008 \\
\hline
\end{tabular}

Dependent Variable: Kepuasan_Kerja 
Dari tabel 9 maka persamaan I analisis jalur pada penelitian ini dapat dijabarkan sebagai berikut:

$$
\begin{aligned}
& Z=\beta 1 X 1+\beta 2 X 2+\mathrm{e} 1 \\
& Z=0,542 X 1+0,589 X 2+0,889
\end{aligned}
$$

Keterangan:

Nilai 0,889 diperoleh dari e $1=\sqrt{1}-0,209=\sqrt{0,791}=0,889$

Pada persamaan I dapat dijelaskan sebagai berikut:

a) Koefisien variabel keselamatan kerja (X1) adalah 0,542 dan bertanda positif artinya setiap perbaikan keselamatan kerja sebesar satu satuan akan meningkatkan kepuasan kerja karyawan sebesar 0,542 satuan dengan asumsi variabel lainnya dianggap tetap.

b) Koefisien variabel kesehatan kerja (X2) adalah 0,589 dan bertanda positif artinya setiap perbaikan kesehatan kerja sebesar satu satuan akan meningkatkan kepuasan kerja karyawan sebesar 0,589 satuan dengan asumsi variabel lainnya dianggap tetap.

c) e1 = jumlah variance kepuasan kerja (Z) yang tidak dapat dijelaskan oleh variabel keselamatan kerja (X1) dan kesehatan kerja (X2) adalah sebesar 0,889.

\section{Analisis Jalur Pengaruh Keselamatan Kerja (X1), Kesehatan Kerja (X2) dan}

\section{Kepuasan Kerja (Z) terhadap Kinerja (Y)}

Tabel 10

Hasil Uji Analisis Jalur Pengaruh Keselamatan Kerja (X1), Kesehatan Kerja (X2) dan Kepuasan Kerja (Z) terhadap Kinerja (Y)

Coefficients $^{\mathrm{a}}$

\begin{tabular}{|ll|c|c|c|c|c|}
\hline \multirow{2}{*}{ Model } & \multicolumn{2}{|c|}{$\begin{array}{c}\text { Unstandardized } \\
\text { Coefficients }\end{array}$} & $\begin{array}{c}\text { Standardized } \\
\text { Coefficients }\end{array}$ & \multirow{2}{*}{ T } & \multirow{2}{*}{ Sig. } \\
\cline { 3 - 5 } & $\mathrm{B}$ & Std. Error & Beta & & \\
\hline 1 & (Constant) & 5,933 & 1,545 & & 3,839 &, 000 \\
& Keselamatan_Kerja &, 311 &, 105 &, 357 & 2,953 &, 004 \\
& Kesehatan_Kerja &, 197 &, 072 &, 318 & 2,736 &, 008 \\
Kepuasan_Kerja &, 177 &, 085 &, 820 & 2,085 &, 041 \\
\hline
\end{tabular}

a. Dependent Variable: Kinerja

Dari tabel 11 maka persamaan II analisis jalur padapenelitian ini dapat dijabarkan sebagai berikut: 


$$
\begin{aligned}
& \mathrm{Y}=\beta 1 \mathrm{X} 1+\beta 2 \mathrm{X} 2+\beta 3 \mathrm{Z}+\mathrm{e} 2 \\
& \mathrm{Y}=0,357 \mathrm{X} 1+0,318 \mathrm{X} 2+0,820 \mathrm{Z}+0,682
\end{aligned}
$$

\section{Keterangan:}

Nilai 0,682 diperoleh dari e $2=\sqrt{1}-0,535=\sqrt{0,465}=0,682$

Pada persamaan II dapat dijelaskan sebagai berikut:

a) Koefisien variabel keselamatan kerja (X1) adalah 0,357 dan bertanda positif artinya setiap perbaikan keselamatan kerja sebesar satu satuan akan meningkatkan kinerja karyawan sebesar 0,357 satuan dengan asumsi variabel lainnya dianggap tetap.

b) Koefisien variabel kesehatan kerja (X2) adalah 0,318 dan bertanda positif artinya setiap perbaikan kesehatan kerja sebesar satu satuan akan meningkatkan kinerja karyawan sebesar 0,318 satuan dengan asumsi variabel lainnya dianggap tetap.

c) Koefisien variabel kepuasan kerja (Z) adalah 0,205 dan bertanda positif artinya setiap perbaikan kepuasan kerja sebesar satu satuan akan meningkatkan kinerja karyawan sebesar 0,205 satuan dengan asumsi variabel lainnya dianggap tetap.

d) e2 = jumlah variance kinerja (Y) yang tidak dapat dijelaskan oleh variabel keselamatan kerja (X1), kesehatan kerja (X2) dan kepuasan kerja (Z) adalah sebesar 0,682 .

\section{Pengujian Hipotesis}

\section{Uji t Hipotesis I}

Dengan tingkat alpha 0,05 dan derajat bebas sebesar 60, diperoleh nilai $\mathrm{t}_{\text {tabel }}$ sebesar 2,000, sedangkan dari perhitungan didapat t pada variabel keselamatan kerja (X1) sebesar 2,953. Maka dapat disimpulkan bahwa $t_{\text {hitung }}>t_{\text {tabel. }}$ Maka $H 0$ ditolak yang berarti koefisien variabel keselamatan kerja (X1) memiliki pengaruh yang signifikan terhadap kinerja (Y), maka terdapat pengaruh signifikan keselamatan kerja terhadap kepuasan pelanggan.Jika nilai variabel keselamatan kerja meningkat maka kinerja karyawan juga meningkat.Ukuran-ukuran kinerja bagi seorang karyawan dapat dilihat dari beberapa faktor salah satunya tentang keselamatan kerja yaitu perasaan nyaman mulai dalam diri tenaga kerja terhadap peralatan keselamatan kerja, peralatan yang digunakan, tata letak ruang kerja dan 
beban kerja yang didapat saat bekerja.

\section{Uji t Hipotesis II}

Dengan tingkat alpha 0,05 dan derajat bebas sebesar 60, diperoleh nilai $t_{\text {tabel }}$ sebesar 2,000, sedangkan dari perhitungan didapat t pada kesehatan kerja (X2) sebesar 2,736. Maka dapat disimpulkan bahwa $t_{\text {hitung }}>t_{\text {tabel }}$.Maka H0 ditolak yang berarti koefisien variabel kesehatan kerja (X2) memiliki pengaruh yang signifikan terhadap kinerja (Y), maka terdapat pengaruh signifikan kesehatan kerja terhadap kinerja.Jika nilai variabel kesehatan kerja meningkat maka kinerja karyawan juga meningkat.Jika nilai variabel kesehatan kerja meningkat maka kinerja juga meningkat.Kondisi fisik, mental dan stabilitas emosi secara umum dapat memiliki pengaruh positif yang mendukung agar kinerja karyawan meningkat.

\section{Uji t Hipotesis III}

Dengan tingkat alpha 0,05 dan derajat bebas sebesar 61, diperoleh nilai $\mathrm{t}_{\text {tabel }}$ sebesar 2,000, sedangkan dari perhitungan didapat t pada keselamatan kerja (X2) sebesar 2,350. Maka dapat disimpulkan bahwa $t_{\text {hitung }}>t_{\text {tabel }}$.Maka H0 ditolak yang berarti koefisien variabel keselamatan kerja (X1) memiliki pengaruh yang signifikan terhadap kepuasan kerja (Z), maka terdapat pengaruh signifikan keselamatankerja terhadap kepuasan kerja.Keselamatan kerja dapat mempengaruhi tingkat kepuasan karyawan. Hal tersebut disebabkan apa bila karyawan mendapatkan perlindungan keselamatan kerja dari perusahan, maka karyawan akan merasa aman, sehingga karyawan memiliki kepuasan terhadap perusahaan.

\section{Uji t Hipotesis IV}

Dengan tingkat alpha 0,05 dan derajat bebas sebesar 61, diperoleh nilai $\mathrm{t}_{\text {tabel }}$ sebesar 2,000, sedangkan dari perhitungan didapat t pada keselamatan kerja (X2) sebesar 2,757. Maka dapat disimpulkan bahwa $t_{\text {hitung }}>t_{\text {tabel }}$.Maka H0 ditolak yang berarti koefisien variabel kesehatan kerja (X2) memiliki pengaruh yang signifikan terhadap kepuasan kerja (Z), maka terdapat pengaruh signifikan kesehatan kerja terhadap kepuasan kerja.Jika nilai variabel kesehatan kerja meningkat maka kepuasan kerja juga meningkat.Pekerjaan karyawan menuntut kesehatan fisik dan mental dapat mengurangi dampak negatif dari risiko kerja sehingga meningkatkan kepuasan kerja karyawan. 


\section{Uji t Hipotesis $\mathbf{V}$}

Dengan tingkat alpha 0,05 dan derajat bebas sebesar 60, diperoleh nilai $t_{\text {tabel }}$ sebesar 2,000, sedangkan dari perhitungan didapat $t$ pada keselamatan kerja (X2) sebesar 2,085. Maka dapat disimpulkan bahwa thitung $>t_{\text {tabel. }}$ Maka H0 ditolak yang berarti koefisien variabel kepuasan kerja (Z) memiliki pengaruh yang signifikan terhadap kinerja (Y), maka terdapat pengaruh signifikan kepuasan kerja terhadap kinerja.Jika nilai variabel kepuasan kerja meningkat maka kinerja juga meningkat. Kepuasan kerja mempunyai pengaruh yang cukup besar terhadap kerja karyawan sehingga jika masalah kepuasan kerja tidak teratasi akan menghambat kelancaran operasional organisasi maupun perusahaan.

\section{Uji t Hipotesis VI}

Dari hasil analisis regresi linier diketahui besarnya nilai jalur path $\beta 1 \mathrm{X} 1 \mathrm{Y}=$ 0,357 , nilai jalur path $\beta 1 \mathrm{X} 1 \mathrm{Z}=0,542$, nilai jalur path $\beta 3 \mathrm{ZY}=0,820$, sehingga hasil pengujian pengaruh langsung variabel keselamatan kerja terhadap kinerja dan pengaruh tidak langsung keselamatan kerja terhadap kinerja dengan kepuasan kerja sebagai variabel intervening dalam analisis path dapat dilihat berikut:

Tabel 11

Uji Perbandingan Pengaruh Langsung dan Pengaruh Tidak Langsung Variabel Keselamatan Kerja terhadap Kinerja

\begin{tabular}{|c|c|c|c|}
\hline Variabel & $\begin{array}{c}\text { Pengaruh } \\
\text { Langsung (a) }\end{array}$ & $\begin{array}{c}\text { Pengaruh tidak } \\
\text { Langsung (b) }\end{array}$ & Hasil \\
\hline KeselamatanKerja & 0,357 & $\begin{array}{c}0,542 \times 0,820 \\
=0,444\end{array}$ & $\begin{array}{c}\mathrm{a}<\mathrm{b}=\mathrm{H} 6 \\
\text { Diterima }\end{array}$ \\
\hline
\end{tabular}

Dengan membandingkan kedua hasil pada tabel 12 dapat ditarik kesimpulan bahwa nilai pengaruh tidak langsung variabel keselamatan kerja terhadap kinerja dengan kepuasan kerja sebagai variabel intervening > nilai pengaruh langsung variabel keselamatan kerja terhadap kinerja, 0,444 > 0,357. Dengan demikian pernyataan hipotesis 6 dapat diterima. Berdasarkan hasil analisis di atas maka memberikan suatu bukti bahwa keselamatan kerja secara tidak langsung memberikan pengaruh signifikan terhadap kinerja karyawan melalui kepuasan kerja sebagai variabel intervening.

\section{Uji t Hipotesis VII}


Dari hasil analisis regresi linier diketahui besarnya nilai jalur path $\beta 1 \mathrm{X} 1 \mathrm{Y}=$ 0,357 , nilai jalur path $\beta 1 \mathrm{X} 1 \mathrm{Z}=0,542$, nilai jalur path $\beta 3 \mathrm{ZY}=0,820$, nilai jalur path $\beta 2 \mathrm{X} 2 \mathrm{Y}=0,318$ dan nilai jalur path $\beta 2 \mathrm{X} 2 \mathrm{Z}=0,589$ sehingga hasil pengujian pengaruh langsung variabel kesehatan kerja terhadap kinerja dan pengaruh tidak langsung keselamatan kerja dan kesehatan kerja terhadap kinerja dengan kepuasan kerja sebagai variabel intervening dalam analisis path dapat dilihat sebagai berikut:

Tabel 12

Uji Perbandingan Pengaruh Langsung dan Pengaruh Tidak Langsung antar Variabel Kesehatan Kerja terhadap Kinerja

\begin{tabular}{|c|c|c|c|}
\hline Variabel & $\begin{array}{c}\text { Pengaruh } \\
\text { Langsung (a) }\end{array}$ & $\begin{array}{c}\text { Pengaruh tidak } \\
\text { Langsung (b) }\end{array}$ & Hasil \\
\hline Kesehatan Kerja & 0,318 & $\begin{array}{c}0,589 \times 0,820 \\
=0,483\end{array}$ & $\begin{array}{c}\mathrm{a}<\mathrm{b}=\mathrm{H} 7 \\
\text { Diterima }\end{array}$ \\
\hline
\end{tabular}

Dengan membandingkan kedua hasil pada tabel 12 dapat ditarik kesimpulan bahwa nilai pengaruh tidak langsung variabel kesehatan kerja terhadap kinerja dengan kepuasan kerja sebagai variabel intervening>nilai pengaruh langsung variabel kesehatan kerja terhadap kinerja, 0,483 >0,318. Dengan demikian pernyataan hipotesis 7 dapat diterima. Berdasarkan hasil analisis di atas maka memberikan suatu bukti bahwa kesehatan kerja secara tidak langsung memberikan pengaruh signifikan terhadap kinerja karyawan melalui kepuasan kerja sebagai variabel intervening.

Koefisien Determinasi Pengaruh Keselamatan Kerja (X1) dan Kesehatan Kerja (X2) terhadap Kepuasan Kerja (Z)

Tabel 13

Korelasi Determinasi Pengaruh Keselamatan Kerja (X1) dan Kesehatan Kerja (X2) terhadap Kepuasan Kerja (Z)

Model Summary

\begin{tabular}{|l|l|r|r|r|}
\hline Model & R & R Square & $\begin{array}{c}\text { Adjusted R } \\
\text { Square }\end{array}$ & $\begin{array}{r}\text { Std. Error of } \\
\text { the Estimate }\end{array}$ \\
\hline 1 &, $457^{a}$ &, 209 &, 183 & 1,679 \\
\hline
\end{tabular}

a. Predictors: (Constant), Kesehatan_Kerja, Keselamatan_Kerja

b. Dependent Variable: Kepuasan_Kerja

Nilai Adjusted $R$ Square hasil analisis data didapatkan sebesar 0,183. Hal ini berarti variasi variabel keselamatan kerja (X1) dan kesehatan kerja (X2) dalam 
menjelaskan variasi variabel kepuasan kerja karyawan $(Z)$ sebesar 18,3\% dan sisanya $81,7 \%$ dijelaskan oleh faktor lainnya seperti budaya organisasi, pendapatan dan iklim kerja.

\section{Koefisien Determinasi Pengaruh Keselamatan Kerja (X1), Kesehatan Kerja (X2) dan Kepuasan Kerja (Z) terhadap Kinerja (Y)}

\section{Tabel 14}

Korelasi Determinasi Pengaruh Keselamatan Kerja (X1), Kesehatan Kerja (X2) dan Kepuasan Kerja (Z) terhadap Kinerja (Y)

\section{Hodel Summary}

\begin{tabular}{|l|l|r|r|r|}
\hline Model & $\mathrm{R}$ & $\mathrm{R}$ Square & $\begin{array}{c}\text { Adjusted R } \\
\text { Square }\end{array}$ & $\begin{array}{c}\text { Std. Error of } \\
\text { the Estimate }\end{array}$ \\
\hline 1 &, $731^{\mathrm{a}}$ &, 535 &, 512 & 1,119 \\
\hline
\end{tabular}

a. Predictors: (Constant), Kepuasan_Kerja,

Kesehatan_Kerja, Keselamatan_Kerja

b. Dependent Variable: Kinerja

Nilai Adjusted $R$ Square hasil analisis data didapatkan sebesar 0,512 atau 51,2\%.

Hal ini berarti variasi variabel keselamatan kerja (X1), kesehatan kerja (X2) dan kepuasan kerja (Z) dalam menjelaskan variasi variabel kinerja karyawan (Y) sebesar 51,2\% dan sisanya 48,8\% dijelaskan oleh faktor lainnya seperti budaya organisasi, pendapatan dan iklim kerja.

\section{KESIMPULAN}

Berdasarkan hasil analisis di atas maka dapat di ambil kesimpulan sebagai berikut:

1. Keselamatan kerja dan kesehatan kerja memberikan kontribusi secara nyata dalam mempengaruhi kinerja Karyawan Bagian Unit Serbuk Evercescent PT Sido Muncul Tbk. Semarang.

2. Keselamatan kerja dan kesehatan kerja memberikan kontribusi secara nyata dalam mempengaruhi kepuasan kerja Karyawan Bagian Unit Serbuk Evercescent PT Sido Muncul Tbk. Semarang.

3. Kepuasan kerja memberikan kontribusi secara nyata dalam mempengaruhi kinerja Karyawan Bagian Unit Serbuk Evercescent PT Sido Muncul Tbk. Semarang.

4. Keselamatan kerja dan kesehatan kerja memberikan kontribusi secara tidak 
langsung dalammempengaruhi kinerja Karyawan Bagian Unit Serbuk Evercescent PT Sido Muncul Tbk. Semarang melalui kepuasan kerja sebagai variabel intervening.

\section{SARAN}

Berdasarkan simpulan diatas peneliti menyarankan untuk melengkapi penelitian yang sudah dilakukan dengan variabel yang belum dimunculkan terkait dengan pengaruhnya terhadap kinerja karyawan PT Sido Muncul Tbk. Semarang.Sum of Square didapatkan pada penelitian ini sebesar 164,215 yang menunjukkan besarnya error yang muncul apabila hanya menggunakan rata-rata kinerja untukmemprediksi hubungan atau korelasi antara variabel bebas dan variabel tidak bebas.Besarnya error ini mengindikasikan terdapat variasi yang tidak dapat dijelaskan oleh model analisis jalur.Semakin bertambahnya variabel signifikan dalam analisis jalur, maka tingkat error semakin berkurang.Hal ini menunjukkan bahwa variabel yang masuk ke dalam persamaan dapat memprediksi hubungan atau korelasi antara variabel dependen dan variabel independen dengan tingkat error lebih kecil.

\section{DAFTAR PUSTAKA}

Arikunto, Suharsimi. 2010. Prosedur Penelitian Suatu Pendekatan Praktik. Jakarta, Rineka Cipta.

Azwar, Saifuddin. 2005. Reliabilitas dan Validitas. Yogyakarta, Pustaka Pelajar.

Budiono, S et.al.2008. Bunga Rampai Hiperkes dan KK. Semarang, Badan Penerbit Universitas Diponegoro.

Davis, Keith dan Newstrom. 2008. Perilaku Dalam Organisasi. Jakarta, Erlangga.

Dessler, Gary, 2004. Manajemen Sumber Daya Manusia, Edisi 9. Jilid 1. Jakarta, Gramedia.

Ferdiani, Destaria. 2012. Pengaruh Partisipasi Anggaran terhadap KinerjaManajerial Pegawai Sekretariat Daerah Provinsi Jawa Tengah: Komitmen Organisasi dan Persepsi Inovasi sebagai Variabel Intervening. Skripsi.Fakultas Ekonomika dan Bisnis UNDIP, Semarang.

Ferdinand, Augusty. 2006. Metode Penelitian Manajemen: Pedoman Penelitianuntuk Skripsi, Tesis dan Disertasi Ilmu Manajemen. Semarang, BadanPenerbit Universitas Diponegoro.

Ghozali, Imam. 2009. Aplikasi Analisis Multivariate dengan Program SPSS. Samarang: Badan Penerbit Univeritas Diponegoro. 
Handoko, T. Hani. 2008. Manajemen Personalia dan Sumberdaya Manusia.

Yogyakarta, BPFE.

Harrington, J.M., dan Gill, F.S. 2005. Buku Saku Kesehatan Kerja. Jakarta, EGC.

Hasibuan, Malayu S. P. 2007. Manajemen Sumber Daya Manusia. Jakarta, Bumi Aksara.

Hessel, Nogi S.Tangkilisan. 2007. Manajemen Publik. Jakarta, Grasindo.

Keban, Yeremias T. Enam Dimensi Strategis Administrasi Publik Konsep, Teoridan Isu. Yogyakarta, Gava Media.

Kreitner, Robert dan Angelo Kinicki. 2005. Perilaku Organisasi. Jakarta, Salemba Empat.

Mangkunegara, Anwar Prabu. 2009. Manajemen Sumber Daya Manusia. Bandung, Remaja Rosdakarya.

Mardalis. 2008. Metode Penelitian. Jakarta, Bumi Aksara.

Mathis, Robert L. \& Jackson. John H. 2007. Manajemen Sumber Daya Manusia. Jakarta, Salemba Empat.

Mondy, R. Wayne. 2008. Manajemen Sumber Daya Manusia. Jakarta, Erlangga. Munandar, Ashar Sunyoto. 2001. Psikologi industri dan Organisasi. Jakarta, UIP.

Narimawati, Umi. 2008. Metodologi Penelitian Kualitatif dan Kuantitatif. Jakarta, Agung Media.

Nitisemito, Alex Soemadji. 2006. Manajemen Personalia, Jakarta, Ghalia Indonesia.

Nurhayat, Wiji. 2012. “Angka Kecelakaan Kerja di RI Masih Tinggi”. (Diakses pada Bulan April 2015) [http://finance.detik.com/].

Paramita, Catarina Cori Pradnya. 2012. Pengaruh Kesehatan dan KeselamatanKerja (K3) terhadap Prestasi Kerja pada PT. PLN (Persero) AJP Semarang.Skripsi.Fakultas Ilmu Sosial dan Ilmu Politik UNDIP,Semarang.

Peraturan Pemerintah Nomor 50 Tahun 2012 tentang Sistem Manajemen Keselamatan dan Kesehatan Kerja (SMK3).

Peraturan Pemerintah Nomor 50 Pasal 1 Tahun 2012 tentang Pengertian Sistem Manajemen keselamatan dan Kesehatan Kerja (SMK3).

Peraturan Pemerintah Nomor 50 Pasal 2 Tahun 2012 tentang Tujuan Sistem Manajemen Keselamatan dan Kesehatan Kerja (SMK3).

Peraturan Pemerintah Nomor 50 Pasal 7 Tahun 2012 tentang Kebijakan Keselamatan dan Kesehatan Kerja (K3).

Pengertian Sistem Manajemen Keselamatan dan Kesehatan Kerja; OHSAS 18001: 2007.

Prawirosentono, Suyadi. 2008. Kebijakan Kinerja Karyawan. Yogyakarta, BPFE. Priyatno, Duwi. 2012. Cara Kilat Belajar Analisis Data dengan SPSS 20. Yogyakarta, Andi. 
Rizky, Achmad S. 2009. Manajemen Pengganjian dan Pengupahan KaryawanPerusahaan. Jakarta, Gramedia Utama.

Robbins, Stephen P, 2006. Perilaku Organisasi. Jakarta, Indeks.

Samsudin, Sadili. 2006. Manajemen Sumber Daya Manusia. Bandung, Pustaka Setia.

Sanusi, Anwar. 2011. Metode Penelitian Bisnis. Jakarta, Salemba Empat.

Satriawan, Leodnardus Ariyanto. 2009. Kajian Kelengkapan Keselamatan danKesehatan Kerja (K3) pada Pekerja Konstruksi di Indonesia.SkripsiFakultas Teknik. Yogyakarta, Universitas Atma Jaya.

Sekaran, Uma. 2006. Metodologi Penelitian untuk Bisnis. Jakarta, Salemba Empat.

Simanjuntak, Payaman J. 2005. Manajemen dan Evaluasi Kinerja. Jakarta: Lembaga Penerbit Fakultas Ekonomi UI.

Stoner, James. 2006. Manajemen. Jakarta, Prenhallindo,.

Sugiyono.2010. Metode Penelitian Kunatitatif Kualitatif dan R\&D. Bandung, Alfabeta.

Suma'mur, 2006.Higene Perusahaan dan Kesehatan Kerja. Jakarta, Gunung Agung.

Sunyoto, Agus. 2008. Manajemen Sumber Daya Manusia. Jakarta, IPWI.

Tarwaka. 2008. Keselamatan Dan Kesehatan Kerja. Surakarta, Harapan Press.

Tjiptono, Fandy. 2009. Strategi Pemasaran. Yogyakarta, Andi.

Wibowo. 2012. Manajemen Kinerja. Jakarta, Rajawali Pers.

Wijaya, Elita Mieke. 2011. Pengaruh Kualitas Pelayanan Terhadap LoyalitasKonsumen, dengan Kepuasan Konsumen sebagai Variabel Intervening (Studi pada Waterpark Semawis Semarang). Skripsi.Fakultas Ekonomikadan Bisnis UNDIP, Semarang.

Wirawan 2009.Evaluasi Kinerja Sumber Daya Manusia. Jakarta, Erlangga.

Witarto, Ery. 2005. Pengaruh Saling Ketergantungan dan Sistem AkuntansiManajemen sebagai Variabel Intervening terhadap Kinerja Manajerial di Perusahaan Manufaktur Semarang.Skripsi.Fakultas Ekonomika dan Bisnis UNIKA Sugijapranata, Semarang.

Yunita, Fanny. 2008. Pengaruh Kepemimpinan Transformasional TerhadapKepuasan Kerja Karyawan UD. Usaha Mandiri Semarang.Skripsi. Ilmu Manajemen Universitas Katolik Soegijapranata, Semarang. 